\title{
The Case For Tax Relief On Private Security Expenditures In South Africa
}

Liza (ESM) Coetzee, University of Pretoria, South Africa

Hanneke du Preez, University of Pretoria, South Africa

Aideen Maher, University of Pretoria, South Africa

\begin{abstract}
Like other countries in transitional democracies, South Africa is experiencing high levels of crime since its first democratic election in 1994. About 83 percent of South Africans believe that the South African Police Service is corrupt and citizens are losing faith in the government to protect them as promised in the Constitution. As a result citizens are paying a large portion of their disposable income on security expenses to protect themselves and their property. Currently no tax relief is available for non-trade related security expenditure, as stated by the South African Revenue Services in 2008 after a public outcry to allow private security expenses as a deduction. This paper urges government to revisit its decision made in 2008. Private security expenses have become a necessity in the daily lives of South Africans. This was demonstrated by surveying four of the largest private security companies in an area of Tshwane Metropolitan Municipality (previously called Pretoria), South Africa. The paper ends by proposing three possible ways of providing tax relief for private security expenses.
\end{abstract}

Keywords: Crime; Private Security Expenses in South Africa; South African Revenue Services; South African Police Service

\section{INTRODUCTION}

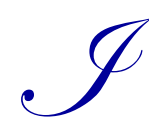

n South Africa crime might be one of the most talked about topics of discussion (Durington, 2009, p. 73), albeit in the National Budget Speech, at work, in grocery shops or at informal get-togethers like barbeques. Countries in transitional democracies often experience high rates of crime, such as Brazil, Poland, and Mozambique, and South Africa is no exception (Shaw, 2002, p. 1). Since the first democratic election in 1994, South Africa is also experiencing increased levels of crime. (Ramen, 2009, p. 22).

Henke Pistorius, dad of murder accused paralympian athlete Oscar Pistorius, told a British Newspaper that South Africans own guns because they cannot rely on the South African Police Service (SAPS) to protect them and blamed the government for failing to protect South Africans (Laing, 2013). Pretorius is charged with premeditated murder of his girlfriend, which he alleges was an accident, believing her to be an intruder in his house. Although the Pistorius family distanced themselves from this controversial statement, it again hi-lighted the crime situation in South Africa, the lack of confidence in the SAPS and the means to which South Africans resort in order to feel safe.

About 83 percent of South Africans believe that the South African Police Services (SAPS) is corrupt and citizens are losing faith in the government to protect them (Transparency International, 2013). Furthermore, due to the SAPS not being able to keep up with the level and volume of crime, private security companies have become accustomed to fulfilling this role (Kokt, 2009, p. 789). As a result, South Africans spend a large portion of their disposable income on security expenses. These include fees to security companies providing armed-response services, alarm systems, tracking devices for their vehicles, and structural changes to their properties, such as palisade, defensive walls, electrical fencing, and 24-hour monitoring systems (Durington, 2009, p. 77).

The South African Revenue Services (2008, p. 1) (SARS) issued Interpretation Note 45 on 30 June 2008 after a public outcry to allow private security expenses as a deduction. It confirmed that "the cost of securing an 
individual's private residence does not qualify as a deduction." Currently no tax relief is available for non-trade related security expenditure (hereafter referred to as 'private security expenses'). Therefore, although individuals pay normal tax at a maximum marginal rate of 40 percent, they spend substantial amounts of after tax money on private security costs.

This paper revisits the question of whether South Africans should receive tax relief for the costs associated with private security. The aim is to offer arguments for why government should reconsider its policy. The paper starts by providing a theoretical foundation and discussing current legislation. Thereafter three arguments are provided for tax relief. Firstly, in terms of the Constitution 1996, taxpayers can expect to be protected by the SAPS in return for paying taxes. Secondly, private security expenses have become a necessity in the daily lives of South Africans. In order to understand the impetus and growing use of private security companies, four of the largest private security companies in an area of Tshwane Metropolitan Municipality (previously called Pretoria) were surveyed. Thirdly, an analogy is drawn between allowing tax relief for private medical costs versus private security costs. The paper concludes with proposals for obtaining tax relief for individuals incurring private security costs.

\section{THEORETICAL FOUNDATION}

A basic overview of the main basic principles (called canons or maxims) for tax policy is a prerequisite for making the case for tax relief in respect of private security costs incurred by South Africans.

Canons or maxims of taxation are the main basic principles or rules set to build an effective tax system and were originally laid down by economist Adam Smith in his famous book The Wealth of Nations ([1776] 2003, p. 1231). Adam Smith gave the following four important canons of taxation which he argued would ensure a fair and effective tax system, namely:

- $\quad$ Canon of Equity (also called fairness of taxes): According to this principle, every person should pay tax depending upon his ability to pay. Rich people should pay higher taxes, because without the protection of the government they could not have earned and enjoyed their income. The concept of fairness is defined as having two dimensions, namely horizontal fairness and vertical fairness (Gildenhuys, 1989, pp. 274-275; Jones \& Rhoades-Catanach, 2010, p. 32). Horizontal fairness is relevant to this paper and is based on the equal tax treatment of those with similar circumstances, for instance, a comparison of income after taking into account medical expenses (Steyn, 2010, pp. 226-227).

- $\quad$ Canon of Certainty: The tax which an individual has to pay should be certain, not arbitrary.

- $\quad$ Canon of Convenience: The mode and timing of tax payment should be as far as possible, convenient to the taxpayers.

- $\quad$ Canon of Economy: The cost of tax collection should be lower than the amount of tax collected.

\section{CURRENT LEGISLATION}

Currently no tax deduction is available in respect of private security expenses incurred. However, expenses incurred in securing business premises are allowed as a deduction. Section 11(a) of the Income Tax Act No.58 of 1962, read with Section 23 states the deductions that taxpayers can and cannot deduct from taxable income. In terms of Section 11(a) a person carrying on a trade may deduct from taxable income any expense actually incurred during the year of assessment in the production of income which are not of a capital nature. Section 23 $(\mathrm{g})$ prohibits the deduction of any expenses that were claimed as a deduction from taxable income in so far as it was not incurred for trading purposes. Furthermore, Section 23(b) disallows private and domestic expenses, except in some instances where the individual earns mainly commission income. Section 11(e) allows wear and tear allowances on capital security expenses in so far incurred for purposes of trade.

During 2008, the National Civilian Safety and Security Action group (Nacissa) stated in a newspaper article that "government neglects its duty to combat crime which compels South African taxpayers to incur expenses to make up for this neglect." Nacissa also encouraged individual taxpayers to claim their private security costs on their tax returns under the "other deductions" section. (Du Plessis, 2009, p. 9). SARS then issued Interpretation Note 45 on 30 June 2008. The aim of the interpretation note was to guide taxpayers in respect of the deductibility of 
private security costs from their taxable income. It did not provide any new write-off and confirmed that "the cost of securing an individual's private residence does not qualify as a deduction." In order to explain what was meant by private and domestic, the interpretation note quoted Judge Beyers in CIR v Hickson, 1960 (1) SA 746 (A) (23 SATC 243: "'Domestic and private expenses' are, I should say, without attempting an exhaustive definition, expenses pertaining to the household, and to the taxpayer's private life as opposed to his life as a trader."

Individuals trading as sole traders can deduct security costs of a non-capital nature incurred in the production of income under Section 11(a). Examples include monthly service fees in respect of a satellite tracking system for motor vehicles, monthly payments to an armed-response company, salary costs of security personnel, and the cost of food and veterinary bills for a guard dog. Capital security expenses will qualify for wear and tear, for example the cost of installing an alarm system, an electric fence, and acquiring a guard dog. If the individual runs his or her business from home, only that portion of security expenses (non-capital and capital) relating to the home office will be deductible. A justifiable method of apportionment has to be used by the taxpayer, for example floor space of the home office as a percentage of total floor space of the building (Section 102 of the Tax Administration Act No. 28 of 2011). The remaining security expenses will not qualify as a deduction as it will be for private purposes.

In the case of a salaried individual who performs his/her work mainly in an office provided by the employer, no deduction will be allowed for any portion of security expenses incurred by him as the full amount will be 'private and domestic' expenses (Section 23(b) of the Income Tax Act). In the case of a salaried individual, who earns mainly commission income and whose duties are performed mainly at his/her home office, a partial deduction will be allowed (Section 23(b) and 23(m)). For example, a medical representative who earns a small basic salary but in addition earns more in commission income based on his sales, than the basic salary. Provided that the home office is specifically equipped and regularly and exclusively (100\%) used for trading purposes, that portion of security expenses relating to the home office (based on floor space) will be deductible. Again no deduction is allowed for the remaining private security expenses.

Private security devices which do not qualify for a tax deduction and that become part of a building's structure may be added to the immovable property's base cost when sold (paragraph 20(1)(e) of the Eighth Schedule to the Income Tax Act). This does not really provide a tax relief but merely means that the taxpayer will not be taxed on the proceeds relating to the security device. It is important to note that the security devices must still be part of the property's structure when the property is sold, such as an electric fence or a burglar alarm system which is integrated into the fabric of a building.

Interpretation Note 45 also points out that donations made to qualifying public benefit organisations that combat crime may be deducted under the normal rules of section 18A of the Income Tax Act. Section 18A allows a maximum deduction equal to 10 percent of the subtotal of taxable income before deducting any qualifying medical costs. It should be noted, however, that the characteristics of a donation is that the donor expects nothing in return (CSARS v Estate Welch's, 2003 (1) SA 257 (CPD (65 SATC 137)). Therefore, it is unlikely that private security expenses will constitute a donation and qualify for deduction under section 18A.

It is clear that currently no tax relief is available for private security expenses incurred by individuals.

\section{THE CASE FOR TAX RELIEF FOR PRIVATE SECURITY EXPENSES}

This section provides three arguments for tax relief in respect of private security expenses.

\section{The Taxpayer-Government Exchange}

The first argument is based on a South African citizen's constitutional rights. In terms of Section 12 and Section 27(1)(a) of the South African Constitution 1996, citizens can expect to receive certain benefits from the government in return for paying taxes. These services include, amongst others, protection services provided by the SAPS and health care services. If citizens perceive the government not to provide these services effectively in return for taxes paid, they would incur private expenditure to compensate for government's inability to provide effective 
services (Steyn, 2010, p. 241). It is common knowledge that South Africans currently perceive security services and public healthcare provided by government as inadequate and therefore incur private security expenses and private healthcare expenses.

\section{The Need for Private Security Expenses in South Africa}

Crime is a reality that everyone (whether directly or indirectly) has to deal with in South Africa. Although the crime statistics released by the SAPS in September 2012 reported a 17.2 percent decrease in murder from 2010 to 2012 (Department of Police, 2012a, p. 20), 15,609 murders were reported for the period April 2011 to March 2012 (Department of Police, 2012b). House and business robberies are also a major concern for the public. In addition, the media in wide broadcasting of violent crime has resulted in the growth of insecurity and fear of crime in the public eye (Department of Labour, 2012, p. 14).

South African citizens perceive the SAPS as unable to deal with their safety and security needs (Department of Labour, 2012, p. 13). The demand by individuals for a more competent security force exceeds the ability of government to provide it (Marks, Shearing, \& Wood, 2009, p. 146). Due to the SAPS not being able to counter the ever-inventive criminals and their ever-changing criminal techniques, private security companies have become accustomed to fulfil this role in the industry (Kokt, 2009, p. 789).

In a survey conducted in 2009 it was found that South Africans spend more on private security as a percentage of GDP than any other nation (Kokt, 2009, p. 789). In 2008, private security costs almost matched the police budget in South Africa (Ramen, 2009, p. 3). Private security expenses are still making up a large percentage of household expenses. This is proved by the fact that the private security industry in South Africa is still growing and is believed to be the largest in the world, reaching an annual turnover of R50 billion in 2011 (Department of Labour, 2012, p. 13).

As mentioned earlier, it should be borne in mind that the media and their reports on crime can be advantageous to the private security industry. The more the media reports on crime, the more a perception of crime escalating is generated and may result in an increase in the demand for private security (Krahmann, 2011). Krahmann (2011) explains it best: ' ... private security companies have ... contributed to the rise of a culture of fear in which the demand for security can never be satisfied and guarantees continuous profits.' The reality is that South Africans incur enormous expenses in preventing and combating crime in order to feel safe and secure.

In order to understand the impetus and growing use of private security companies in South Africa, four of the largest private security companies in an area in Tshwane Metropolitan Municipality (formerly called Pretoria) were surveyed. Private security companies were interviewed (as opposed to individuals who had been victims of crime) as these companies work closely with the SAPS in handling numerous incidents on a daily basis. The sampling process was a combination of convenience and purposive sampling. Being a phenomenological study, namely participants who have had direct experience with the topic, the sample size was small (Leedy \& Ormrod, 2005, p. 139). The researcher conducted telephonic interviews with the managers of the chosen private security companies using a structured questionnaire.

The results of the survey demonstrate the inability of the SAPS to cope with the level and volume of crime currently experienced in South Africa. A majority of the respondents reported that their clients experienced on average a three hour or longer wait time for the SAPS to respond to their emergency calls. On average the four security companies themselves reported a response time of 10 minutes or less to emergency calls. Participants were of the opinion their companies contribute significantly to efforts to prevent crime to supplement what the SAPS can do, such as:

- $\quad$ Respond fast to emergency calls, arrest the suspect, and wait for the SAPS to arrive and take custody of the suspect;

- $\quad$ Monitor and patrol areas with high incidents of crime;

- Increased visibility in order to discourage criminals;

- $\quad$ Confront suspect vehicles and persons;

Copyright by author(s); CC-BY 
- $\quad$ Follow up on suspect persons or vehicles when reported by clients;

- $\quad$ Liaise with the community and the SAPS.

The responses suggest that citizens, who can afford it, contract personal security companies almost out of necessity as opposed to a 'nice-to-have.'

\section{Analogy between Medical Cost and Private Security Costs}

The third argument lies in the analogy between private security costs and private health care costs incurred by individuals. As mentioned earlier, the Constitution provides citizens the right to security services (provided by the SAPS) and state health care services in return for taxes paid. Due to the fact that government provides these services inadequately, citizens are privately incurring these costs. Although section 18, 6A and 6B of the Income Tax Act are providing tax relief for private health care expenses, no tax relief is provided for private security expenses. This seems to be unfair and give rise to an inequality.

\section{PROPOSALS FOR ACHIEVING TAX RELIEF}

Three possibilities are proposed for providing relief in respect of private security expenses.

\section{Tax Deduction for Private Security Expenses}

The first proposal is allowing an income tax deduction for private security expenses. Further research is necessary to determine the amount of the deduction, namely whether these costs should be allowed in full or based on a formula. Furthermore, if the private security industry is highly effective and the cost of private security is kept low, a tax relief in the form of a tax deduction would result in a stronger economy, reduced crime rates, and higher long term productivity (Ramen, 2009, p. 13).

\section{Tax Rebate for Private Security Expenses}

The tax relief can be provided by way of a tax credit as opposed to a tax deduction, as an argument exists that a tax credit provides a more equitable form of relief than a deduction. This is the reason why the deduction for private health care expenses is being converted to a rebate. It is argued that the relative value of the relief does not increase with higher income levels, as in the case of a deduction (South Africa, 2012, p. 1). A counter argument is that a taxpayer, who pays tax at a higher rate, should be relieved at that higher rate.

\section{Outsourcing Security Services to Private Security Companies}

The third proposal would be for government to outsource security services to private security companies. These companies would then be paid by government from tax money and not by taxpayers out of after tax earnings reducing their disposable incomes. Loader (in Ramen, 2009, p. 16) points out that, if public security was privatised it would result in better management of funds and better quality service delivery. Although there is merit in this argument, Benson (in Ramen, 2009, p. 19) pointed out that private organisations have one main goal, namely to make profit which could result in private organisations cutting costs that would lead to inferior private security service delivery. following:

Further disadvantages pointed out by Benson (in Ramen, 2009, p. 21) of privatising public security are the

- $\quad$ The taxpayer would not be able to select the service provider of his choice, since government would decide which security company would provide the security services.

- $\quad$ Once government decides on the private security providers that will be used, it could result in these providers delivering sub-standard and inferior services. 
Effective regulation of the private security industry would most likely solve the abovementioned disadvantages. It is suggested that outsourcing of security services will make taxpayers feel that they are getting 'more value' for the taxes they pay and is a possibility which could be researched further.

\section{CONCLUSION}

This paper used three arguments for tax relief in respect of private security expenses to urge government to revisit its decision made in 2008. The first argument is that taxpayers are expecting government to deliver in terms of the Constitution in return for the taxes paid. Secondly, private security expenses have become a necessity in the daily lives of South Africans. This was demonstrated by surveying four of the largest private security companies in an area of Tshwane Metropolitan Municipality (previously called Pretoria). The last argument draws an analogy between private health care expenses and private security expenses. Although tax relief is provided for private health care services, no relief exists for private security expenses. This seems to be unfair and give rise to an indirect inequality in light of Adam Smith's canons.

Of course arguments can be raised to counter the ones offered in this paper. For example, some could argue that tax relief, if granted, may not meet the criteria of equality because some South African citizens can simply not afford private security expenses. But these concerns could be addressed. In poorer communities more affordable methods are used to supplement security services offered by the SAPS, such as community patrols and neighbourhood watches and there could be ways to also provide relief to them.

The main implication of this paper is that the government should reconsider allowing tax relief for private security expenses, as it is clear that citizens will, in at least the short term continue to bear a significant burden in order to feel secure in South Africa. While this paper specifically looks at the situation in South Africa, future research should examine this issue in other transitional societies to compare how private security expenses incurred by citizens are treated.

\section{AUTHOR INFORMATION}

Mrs Liza (ESM) Coetzee is a consulting chartered accountant and a senior lecturer at the University of Pretoria, South Africa. She lectures taxation on a postgraduate level and acts as a research supervisor on a postgraduate level. Her research interests centres on socio-economic issues such as the tax deductibility of expense incurred by parents caring for their disabled children and changing employment relations. She is a mother of four. Mrs Liza Coetzee, Department of Taxation, Main campus EMS Building 4-14, University of Pretoria, Private Bag X20, Hatfield, South Africa, 0028. E-mail: Liza.Coetzee@ up.ac.za (Corresponding author)

Hanneke du Preez is a consulting chartered accountant and senior lecturer at the University of Pretoria, South Africa. She lectures taxation on an undergraduate level and does research supervision on a postgraduate level. She has been involved in education, first as a secondary school teacher specialising in Accounting and Geography studies, and currently as senior lecturer in taxation. Her research interests centres on the teaching practices of taxation students and the assessment practices of professional board examinations, specifically related to open-book assessment. Mrs Hanneke du Preez, Department of Taxation, Main campus EMS Building 4-3, University of Pretoria, Private Bag X20, Hatfield, South Africa, 0028. E-mail: Hanneke.Dupreez@up.ac.za

Aideen Maher, Department of Taxation, Main campus, EMS Building 4-14, University of Pretoria, Private Bag X20, Hatfield, South Africa, 0028.

\section{REFERENCES}

1. $\quad$ CSARS v Estate Welch's (1) SA 257 (CPD (65 SATC 137). (2003).

2. $\quad$ CIR v Hickson (1) SA 746 (A) (23 SATC 243). (1960).

3. Du Plessis, L. (2009). Crime makes us pay in more ways than one. TAXtalk January/February.

4. Durington, M. (2009). Suburban fear, media and gated communities in Durban, South Africa. Home Cultures, 6(1). 
5. Gildenhuys, J. S. H. (1989). Owerheidsfinansies. Pretoria: Van Schaik.

6. Jones, S. M., \& Rhoades-Catanach, S. C. (2010). Principles of taxation for business and investment planning. Boston, MA: McGraw-Hill Irvin.

7. Kokt, D. (2009). A model for establishing a quality culture in a major private security company. Routledge, 20(8).

8. Krahmann, E. (2011). Beck and beyond: Selling security in the world risk society. British International Studies Association.

9. Laing, A. (2013). Oscar Pistorius's father blames South African gun culture on ANC. The Telegraph, 3 March. [Online] Retrieved 2013-07-15 from http://www.telegraph.co.uk/news/worldnews/oscarpistorius/9905927/Oscar-Pistoriuss-father-blames-South-Africas-gun-culture-on-ANC.html

10. Leedy, P. D., \& Ormrod, J. E. (2005). Practical research: Planning \& design ( $8^{\text {th }}$ ed.). Pearson Education Inc.

11. Marks, M., Shearing, C., \& Wood, J. (2009). Who should the police be? Finding a new narrative for community policing in South Africa. Routledge, 10(2).

12. Ramen, D. (2009). Taxation and security expenditure for individuals in South Africa. (Unpublished Masters mini-dissertation). Pretoria: University of Pretoria.

13. Shaw M. (2002). Crime, police and public in transitional societies. Transformation: Critical Perspectives on Southern Africa. [Online] Retrieved 2013-07-17 from http://muse.jhu.edu/journals/transformation/toc/trn49.1.html

14. Smith, A. [1776] (2003). The wealth of nations. New York, NY: Modern Library.

15. South Africa. (1962). Income Tax Act, No. 58 of 1962. Pretoria: Government Printer.

16. South Africa. (2011). Tax Administration Act, No. 28 of 2011. Pretoria. Government Printer.

17. South Africa. (2012). Explanatory memorandum on the taxation law amendment bill, 2012. [Online] Retrieved 2013-07-15 from http://www.sars.gov.za/AllDocs/LegalDoclib/ ExplMemo/LAPD-LPrep-EM2012-01\%20-\%20Explanatory\%20Memorandum\%20

Taxation\%20Laws\%20Amendment\%20Bill\%202012.pdf

18. South Africa. Department of Labour. (2012). ECC private security report, 2012. [Online]. Retrieved 201307-15 from https://www.labour.gov.za/downloads/documents/useful-documents/basic-conditions-ofemployment/eccprivatesecurityreport2012.doc/view?searchterm=ECC private security report 2012

19. South Africa. Department of Police. (2012a). SAPS crime statistics overview RSA 2011/2012. [Online]. Retrieved 2013-07-15 from http://www.saps.gov.za/statistics/reports/crimestats/2012/ downloads/crime_statistics_presentation.pdf

20. South Africa. Department of Police. (2012b). SAPS crime statistics per category 2011/2012. [Online]. Retrieved 2013-07-15 from http://www.saps.gov.za/statistics/reports/crimestats/2012/ categories/murder.pdf

21. South Africa (Constitution). (1996). Constitution of the Republic of South Africa, No 108 of 1996. Pretoria: Government Printer. [Online] Retrieved 2013-07-17 from http://www.info.gov.za/ documents/constitution/1996/a108-96.pdf

22. South African Revenue Service. (2008). Interpretation Note: No 45. 2008. [Online] Retrieved 2013-07-17 from www.sars.gov.za/legal and policy

23. Steyn, T. (2012). A conceptual framework for evaluating the tax burden of individual taxpayers in South Africa. (Unpublished PhD-dissertation). Pretoria: University of Pretoria.

24. South Africa. (1962). Income Tax Act, No. 58 of 1962. Government Gazette. [Online] Retrieved 2013-0715 from http://www.acts.co.za/tax/index.htm

25. Transparency International. (2013). Global corruption barometer 2013. [Online] Retrieved 2013-07-17 from http://www.transparency.org/gcb2013/results 
NOTES 